American Journal of Microbiology 1 (1): 1-8, 2010

ISSN 1948-982x

(C) 2010 Science Publications

\title{
Profiling and Curing from Shigella Spp Isolated from Plasmid Diarrheal Patients
}

\author{
Munim R. Ali, Raad N. Hasan, Ali I. Mohammed and Ahmaed A. Abbas \\ Department of Biology, University of Al-Mustansiryah, College of Science, Baghdad, Iraq
}

\begin{abstract}
Problem statement: Shigellosis is a common infectious disease especially in underdeveloped countries. The bacteria are primarily transmitted through the faecal-oral route. The inflammatory process of acute Shigella infection affects the colon and is characterized clinically by fever, cramping abdominal pain with frequent loose stools that might contain mucus, pus and blood. Approach: This study determined the susceptibility of Shigella isolates to antibiotics. Afterward, plasmid isolation from pathogenic Shigella will carried out to achieved information concerning to the presence of plasmid DNA in Shigella isolates. Plasmid curing will be done to seek correlation between resistance to antibiotics and plasmid occurrence in Shigella. Results: We found that the incidence of diarrhea in male is almost similar to female. The distribution of Shigella spp., in male more than in female represented 54.54 and $45.46 \%$ respectively. Conclusion: Approximately $89.5 \%$ of the diarrhea cases had no bacterial pathogen, suggested of probability of viral infection.
\end{abstract}

Keywords: Shigella spp., plasmid, antibiotic resistance, antibiotics, diarrheal patients

\section{INTRODUCTION}

Shigellosis is a common infectious disease especially in underdeveloped countries. WHO bulletin concluded that, $99 \%$ of the estimated 165 million cases of Shigella diarrhoea annually occurs in developing countries. Majority $(69 \%)$ of episodes are seen in children under five years of age 3 . This is attributable to personal hygiene and sanitary conditions which promote spread of organisms like Shigella and other enteric pathogens (Kotloff et al., 1999; Hawari, 2008).

Four serogroups (or species) of shigella have been described including group A (Shigella dysenteriae), group B (Shigella flexneri), group C (Shigella boydii) and group D (Shigella sonnei). These groups are further classified into serotypes and sub-serotypes. This serotyping scheme uses the polysaccharide $\mathrm{O}$ antigen found in the outer part of the cell wall. Shigella organisms are highly virulent. A very small inoculumas little as ten microorganisms-can cause disease in humans (Ozuah, 1998; Raja et al., 2009). Antibiotic resistance among enteric pathogens is of great importance in the developing world, where the rate of diarrhoeal disease is high. Continued mismanaged selective pressure has contributed towards the emergence of multiple drug resistant bacteria and that has been regarded as an inevitable genetic response to antimicrobial therapy (Smith et al., 2003).Frequency of antibiotic resistance among Shigella species is growing up and has been reported in various studies globally.
The ability of a genetic marker for transferring from one bacterium to another through conjugation or transformation provides a good presumptive evidence for the involvement of plasmid, particularly if the transfer frequency is high. Moreover, loss of certain genetic markers as a result of treatment of bacterial cell to plasmid curing agents also suggests for the plasmidial nature of the marker (Mesas et al., 2004; Altalhi, 2007). The inhibition of conjugational transfer of antibiotic resistance plasmid can be exploited to reduce the spread of antibiotic resistance plasmid in the ecosystem. Inhibition of plasmid replication at various stages, as shown in the "rolling circle" model (replication, partition, conjugal transfer) may also be the theoretical basis for the elimination of bacterial virulence in the case of plasmid mediated pathogenicity and antibiotic resistance (Alhaj et al., 2008).

\section{MATERIALS AND METHODS}

Sample collection: Stool samples were collected from patients with diarrhoea admitted to the Baghdad teaching laboratory between September 2008 and December 2008. All submitted stool samples received in transport media (Phosphate buffered saline) and were inoculated on MacConkey, Xylose-Lysine Deoxycholate (XLD) agar and for enrichment in Selenite-F broth and then incubated at $37^{\circ} \mathrm{C}$ for $24 \mathrm{~h}$ in aerobic environment. After overnight incubation, Selenite-F broth was subcultured on SalmonellaShigella agar.

Corresponding Author: Raad N. Hasan, Department of Biology, University of Al-Mustansiryah, College of Science, Baghdad, Iraq 
Bacterial identification: Colonies morphologically suggestive of Shigella species were identified by conventional biochemical reactions (urea, citrate, triple sugar iron, indole, motility) and for further checked by API 20 E (Bio Murex, France).

Serotypig: Shigella isolates were grouped serologically by a slide agglutination test with antisera (Becton Dickinson and Company, Franklin Lakes, NJ, USA).

Antimicrobial susceptibility testing: Was performed with the standard disk diffusion method according to the National Committee for Clinical Laboratory Standards (2002) (NCCLS). A total of 6 antimicrobials, ampicillin, chloramphenicol, trimethoprimsulfamethoxazole, ceftriaxone, ciprofloxacinand tetracycline, were tested.

Plasmid curring: The procedure of Zurkowski and Lorkiewicz (1978) was used for heat curing. Overnight YEM broth cultures were inoculated into PA broth. The cultures were incubated in $35,37,40$ and $45^{\circ} \mathrm{C}$ water bathsand given daily $5 \mathrm{sec}$. blending in a Vortex mixer for aeration. The cultures were transferred to fresh broth at weekly intervals. After heat treatment, the cultures were plated on YEM agar and the plasmid profiles of single colony isolates were observed.

Curing of plasmids by ethidium bromide: Techniques were similar as described by Ansari and Khatoon (1997). The plasmids were studied for curability in isolated colony. N.B. broth $(5 \mathrm{~mL})$ tubes containing graded concentration of Ethidium Bromide (EBr) were incubated with log phase cultures of Shigella isolates host bearing $\mathrm{R}$ plasmids to give a 20 fold dilution. A control tube lacking $\mathrm{EBr}$ was always included. All the tubes were incubated over night at $37^{\circ} \mathrm{C}$. The contents of the control tube and of the EBrcontaining tubes were plated on $\mathrm{MA}$, to obtain isolated colonies. After overnight incubation at $37^{\circ} \mathrm{C}$, these were replicated on antibiotics containing plates to check for the loss (or its absence) of antibiotic resistance determines.

Curing of plasmids by sub culturing: Kamiunten (1990) method used with some modified as fallow, Shigella isolates had optimum growth temperature of $37^{\circ} \mathrm{C}$ a. Bacterial strains were grown in $5 \mathrm{~mL}$ of YP medium at $37^{\circ} \mathrm{C}$ for $24 \mathrm{~h}$ and then $0.1 \mathrm{~mL}$ of the cell suspension was transferred to $5 \mathrm{~mL}$ of the fresh same medium and shake-cultured at $37^{\circ} \mathrm{C}$ for $24 \mathrm{~h}$. After twelve times of subculturing under the same conditions, the cultures were diluted with sterile distilled water and plated on YP agar medium. After 2 or 3 days of incubation at $37^{\circ} \mathrm{C}$. These clones resulted from streaking on the medium were subcultured for examination of their plasmid content.

Plasmid DNA isolation: The alkaline lyses method (Kado and Liu, 1981) was used for plasmid DNA isolation.

Agarose gel electrophoresis: About $0.8 \%$ agarose in TBE buffer was used as described (Maniatis, 1982).

\section{RESALTS}

In this study four hundred patient with acute diarrhea were involved. They were 232 males (58\%) and 168 females (42\%). The age ranged between months to 70 years as show in (Table 1).

Like many other developing countries, diarrheal diseases are among the main health problems in Iraq, During the study period, 400 stool samples were received were found to be positive for Shigella spp., 11 isolates (2.75\% from total samples), 42 samples gave positive results, but the results were canceled and focusing on Shigella spp., (26.1\% from total isolates). The frequency of isolation of Shigella spp., in our study was higher than that of some developing countries (5$10 \%$ ) (Katouli et al., 1990); however, there are reports from Lao People's Democratic Republic (16.8\%) and Tanzania (12.2\%), indicating similar high frequencies (Gascon et al., 2000). The rate of isolation of Shigella spp., in developed countries is about $1 \%$ (Essers et al., 2000).

According to the results, the distribution of Shigella spp., in male more than in female represent 54.54 and $45.46 \%$ respectively. In this study we found that the incidence of diarrhea in male is almost similar to female. However recent studies showed that no sex difference in the occurrences of diarrhea was found as the risk factors associated with diarrhea are environmental and sociodemographic rather than biological factors (Parashar et al., 1998).

Table 1: General description of gender for patients with acute diarrhea

\begin{tabular}{|c|c|c|c|}
\hline \multirow[b]{2}{*}{ Age group } & \multirow[b]{2}{*}{ Diarrheal number } & \multicolumn{2}{|c|}{ Gender } \\
\hline & & Male & Female \\
\hline 1 month-10 year & 289 & 168 & 121 \\
\hline $10-20$ year & 20 & 13 & 7 \\
\hline 20-30 year & 19 & 12 & 7 \\
\hline $30-40$ year & 27 & 15 & 12 \\
\hline 40-50 year & 18 & 10 & 8 \\
\hline $50-60$ year & 18 & 9 & 9 \\
\hline $60-70$ year & 9 & 5 & 4 \\
\hline Total & 400 & 232 & 168 \\
\hline
\end{tabular}


Table 2: Distribution Shigella spp., with age group and gender

\begin{tabular}{lcll}
\hline & \multicolumn{3}{c}{ Gender } \\
Age group & Shigella spp., & Male & Female \\
\hline 1 month-10 year & 9 & 5 & 4 \\
10-20 year & 1 & - & 1 \\
20-30 year & - & - & - \\
30-40 year & - & - & - \\
40-50 year & - & - & - \\
50-60 year & - & 1 & - \\
60-70 year & 1 & $6(54.54)$ & $5(45.46)$ \\
Total & 11 & & \\
\hline
\end{tabular}

Table 3: Serogroups of Shigella according to gender

\begin{tabular}{llll}
\hline Gender & Shigella flexneri & Shigella boydii & Shigella dysentriae \\
\hline Male & 4 & 2 & 1 \\
Female & 4 & - & - \\
Total & 8 & 2 & 1 \\
\hline
\end{tabular}

The first age group (1 month-10 year showed the high number of isolates (9 isolates), while the lowest incidence were in (10-20 year) and (60-70 year) one isolate to both of them as shown in Table 2. The average age of the patients with Shigella infection in our study was similar to some reports (MoezArdalan et al., 2003), indicating a rise in the average age of Shigella infection to older (aged 12 or more than 12 years) compared to some reports from other developing countries, where the group of one or more than one to less than five year (s) of age had the highest frequency of isolation (Ahmed et al., 1997). While (Rawashdeh et al., 1994) noticed that the age group for peak Shigella incidence was 1-4 years.

Shigella flexneri was the most predominant Serogroups (72.7\%) followed Shigella boydii (18.2\%) and Shigella dysentriae being the least common isolate $(9.1 \%)$ (Table 3). These results were agreed with the finding (Chuang et al., 2006) they showed that $S$. flexneri was the most prevalent serotype $(73.3 \%)$ followed by S. sonnei $(26.5 \%)$. while the results of some of studies that have been done in Iran, Israel, the United States, Canadaand other developed countries. Revealed that $S$. sonnei is the predominant species in those countries and is more common in children than in adults. However, in Taiwan and Bangladesh the infections are mostly caused by $S$. flexneri. It has been suggested that factors involved in natural selection may have been the main reason for these discrepancies (Farshad et al., 2006). Though it is in contrast to the finding of developed world but is similar to that in other countries where diarrheal diseases are endemic too (Wasfy et al., 2000).

\section{DISCUSSION}

The results of the antibiotic susceptibility tests for four species of Shigella isolates are shown in Table 3. In total, of the 11 isolates, $18.18 \%$ (2 isolates) were resistant to Ciprofloxacin, $36.36 \%$ (4 isolates) were resistant to Chloramphenicol, 54.54\% (6 isolates)were resistant to Cefotaxime, Cefepime, Cefixime and Ceftazidium, $63.63 \%$ (7 isolates) were resistant to Azithromycinand $72.72 \%$ (8 isolates) were resistant to Tetracycline and Erythromycin. Resistance to Pipracillin, Amoxacillin, Cephalothin, Kanamycin and Rifampicin was $100 \%$ detected. These results agree with (MoezArdalan et al., 2003) The sowed the most common resistance among Shigella spp., was to tetracycline $(73.5 \%)$, trimethoprim-sulphamethoxazole (70.4\%) and amoxicillin-clavulanic acid (50.0\%). S. flexneri isolates were most frequently resistant to tetracycline (82.2\%), amoxicillin-clavulanic acid $(82.2 \%)$. And disagree with (Banajeh et al., 2001) the noticed most of the Shigella isolates were susceptible to nalidixic acid and cefotaximeand resistant to the other antibiotics. Mandomando et al. (2009) showed that Shigella isolates are resistant mostly to the most available, inexpensive antibiotics by various molecular mechanisms but remain susceptible to ciprofloxacin, which is the first line for empirical treatment of shigellosis in the country.

The results of the antimicrobial susceptibility tests showing a relatively higher number of multidrugresistant isolates and especially the emergence of resistance to Aminoglycosides and third-generation cephalosporins indicates that designing a surveillance system for antimicrobial resistance in Iraq and the introduction of integrated guidelines for the appropriate use of antibiotics are urgently needed. Multiple resistances with the patterns of Pipracillin, Amoxacillin, Cephalothin, Kanamycin and Rifampicin noticed in all the isolates are shown in Table 4. S. flexneri were showed multiple resistance ranging from 7-13 antibiotic, most of these isolates resistant 12-13 antibiotics.

In the other hand Shigella boydii and Shigella dysentriae showed low resistance pattern they were 6 and 7, respectively. According to the susceptibility of the majority of Shigella spp., to Ciprofloxacin and Chloramphenicole in this study, recommend the morereadily available drug. Chu et al. (1998) indicated multiresistance (resistance to four or more agents) was more common in S. flexneri than in Shigella sonnei. A higher multidrug-resistant rate among Shigella isolates was found in our study. Although only limited numbers of strains were examined, this result may showed a clear trend that multidrug-resistant Shigella in Asian countries has been increasingand this may be due to a worsening situation with regard to antibiotic overuse in both humans and animals (Kuo et al., 2008). 
Table 4: Number of antibiotic resistance and plasmid bands of Shigella spp.,

\begin{tabular}{|c|c|c|c|}
\hline Isolate (s) & Antibiotic resistance pattern & $\begin{array}{l}\text { No. of } \\
\text { antibiotic } \\
\text { resistance }\end{array}$ & $\begin{array}{l}\text { No. of } \\
\text { plasmid } \\
\text { bands }\end{array}$ \\
\hline SF1 & $\begin{array}{l}\text { CAZ,AZM,K,RA, E,CFM, } \\
\text { FEP,CTX,T,KF,AX,PRL }\end{array}$ & 12 & 1 \\
\hline SF2 & $\begin{array}{l}\text { CAZ, K,RA,E,CFM,FEP, } \\
\text { CTX,T,KF,AX,PRL }\end{array}$ & 11 & 1 \\
\hline SF3 & $\begin{array}{l}\text { CAZ,AZM,K,RA, E,CFM, } \\
\text { FEP,CTX,T,KF,AX,PRL }\end{array}$ & 12 & 1 \\
\hline SF4 & $\begin{array}{l}\text { CAZ,AZM,K,RA,C,E, } \\
\text { CFM,FEP,CTX,T,KF,AX,PRL }\end{array}$ & 13 & 2 \\
\hline SF5 & $\begin{array}{l}\text { CAZ,AZM,K,RA, E,CFM,FEP, } \\
\text { CTX,T,KF,AX,PRL }\end{array}$ & 12 & 1 \\
\hline SF6 & $\mathrm{K}, \mathrm{RA}, \mathrm{C}, \mathrm{E}, \mathrm{T}, \mathrm{KF}, \mathrm{AX}, \mathrm{PRL}$ & 8 & 1 \\
\hline SF7 & $\mathrm{K}, \mathrm{RA}, \mathrm{E}, \mathrm{T}, \mathrm{KF}, \mathrm{AX}, \mathrm{PRL}$ & 7 & 1 \\
\hline SF8 & $\begin{array}{l}\text { CAZ,AZM,K,RA,C,E,CFM, } \\
\text { FEP,CTX,T,KF,AX,PRL }\end{array}$ & 13 & 2 \\
\hline SB1 & AZM,K,RA, KF,AX,PRL,CIP & 7 & 1 \\
\hline SB2 & AZM,K,RA, KF,AX,PRL,CIP & 7 & 1 \\
\hline SD1 & $\mathrm{K}, \mathrm{RA}, \mathrm{C}, \mathrm{KF}, \mathrm{AX}, \mathrm{PRL}$ & 6 & 1 \\
\hline
\end{tabular}

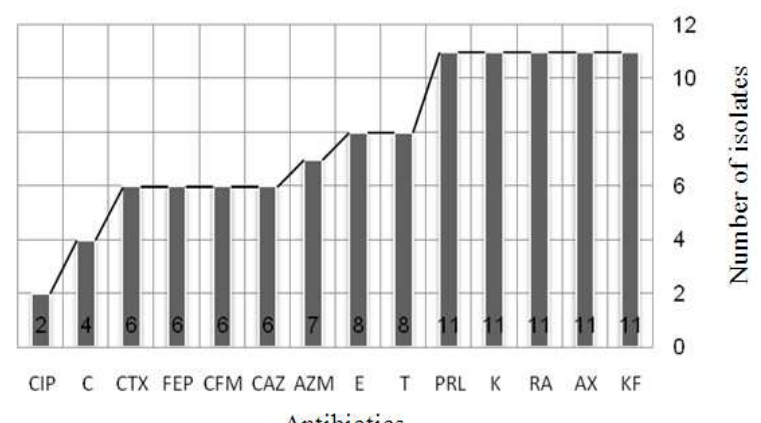

Antibiotics

Fig. 1: Drug susceptibility patterns of Shigella spp., isolated from patients presenting at hospitals in Baghdad

To reveal whether the multiple drug resistance phenomenons in the Shigella spp., was plasmid mediated, 11 Shigella spp., isolates were screened for plasmid. Numerous plasmid patterns were found in the isolates. Representative plasmid profiles from each Shigella species are shown. Many isolates demonstrated the large virulence plasmid (180-220 $\mathrm{kb})$. This plasmid was not used for pattern comparison of isolates because of its documented instability on subculture (Sansonetti et al., 1981; Shafik et al., 2007). All the Shigella spp., isolates were found to harbour a single and similar plasmid except isolates 4 and 8 had which in two plasmids bands are included in Fig. 1 and Table 1 for comparison purposes. Plasmid fingerprinting is a helpful tool in epidemiological studies, particularly if there is a spectrum of plasmid profiles in the population. In our study, numerous plasmid patterns were found in each of the Shigella species. Tacket et al. (1984) also found multiple plasmid profiles in all Shigella species. Litwin et al. (1991) studied 74 Shigella spp., isolates, they found Plasmid patterns for each species were distinct. A total of 57 of $74(77 \%)$ Shigella flexneri strains could be placed into seven plasmid patterns, 70 of 79 (89\%) Shigella sonnei strains could be placed into seven patterns, 12 Shigella boydii strains could be placed into six patternsand each of 3 Shigella dysenteriae strains differed.

It was found this study there were relation between plasmid bands and multiple antibiotic resistant pattern. As shown in (Table 4). These results agree with Haider et al. (1985) who found that multiresistant clinical isolates generally harbor a single large transmissible plasmid.

Studies demonstrating the relation of plasmid and drug resistance in clinical isolates of Shigella spp., by curing are scanty in our country. Curing of plasmids was carried out with ethidium bromide, sub culture and temperature at $15-30^{\circ} \mathrm{C}$. Plasmid curing was achieved by growing the strains, treatment with temperature at $15-30^{\circ} \mathrm{C}$ and Ethidium bromide, while the lowest curing efficiencies was obtained using subculture as shown in Table 5-7. The plasmid elimination was accompanied by drastic changes in antibiotic resistance and morphology of the colonies (Raja and Selvam, 2009). All isolates those were resistant to ciprofloxacin and chloramphenicol, lose resistance when treated with temperature at 15 and increase inhibition zone diameter when treated with temperature at $30^{\circ} \mathrm{C}$.while in sub culturing and Ethidium bromide treatment chloramphenicol resistance remained, as well as isolates gave low resistant (inhibition zone) to ciprofloxacin. In another hand third generation cephalosporin affected by both curing treatment temperature at $15-30^{\circ} \mathrm{C}$ and Ethidium bromide. The results showed isolates death in ethidium bromide at 6.25 concentrations.

After curing experiments the loss of antibiotic resistance was concomitant with the loss of plasmid content so that the results showed that most cured isolates had lost their antibiotic resistance to almost antibiotics tested. This indicates that the resistance determinants of tested antibiotics were located on plasmids. Furthermore, this study suggested that loss of antibiotic resistance phenotype in cured strains may be either because of mutation as a result of incubation in the presence of the curing, or genes encoding resistance to the antibiotics. 
Am. J. Microbiology 1 (1): 1-8, 2010

Table 5: Curing of Shigella spp., plasmid by heat

\begin{tabular}{|c|c|c|c|c|c|c|c|c|c|c|c|c|c|c|c|}
\hline Treatment & Isolate & CIP & $\mathrm{C}$ & $\mathrm{KF}$ & $\mathrm{E}$ & AZM & $\mathrm{K}$ & RA & PRL & $\mathrm{AX}$ & $\mathrm{T}$ & CAZ & CTX & FEP & CFM \\
\hline $\mathrm{BC}$ & & 25 & 30 & $\mathrm{R}$ & $\mathrm{R}$ & 12 & 13 & $\mathrm{R}$ & $\mathrm{R}$ & $\mathrm{R}$ & $\mathrm{R}$ & 11 & $\mathrm{R}$ & $\mathrm{R}$ & $\mathrm{R}$ \\
\hline H15 & 1 & 31 & 35 & $\mathrm{R}$ & $\mathrm{R}$ & 12 & 13 & $\mathrm{R}$ & $\mathrm{R}$ & $\mathrm{R}$ & $\mathrm{R}$ & 11 & 28 & 11 & 25 \\
\hline $\mathrm{H} 30$ & & 35 & 38 & $\mathrm{R}$ & $\mathrm{R}$ & 12 & 13 & $\mathrm{R}$ & $\mathrm{R}$ & $\mathrm{R}$ & $\mathrm{R}$ & 11 & 31 & 20 & 32 \\
\hline $\mathrm{BC}$ & & 22 & 32 & $\mathrm{R}$ & 12 & 20 & 12 & 9 & $\mathrm{R}$ & $\mathrm{R}$ & $\mathrm{R}$ & 10 & $\mathrm{R}$ & $\mathrm{R}$ & $\mathrm{R}$ \\
\hline H15 & 2 & 21 & 34 & $\mathrm{R}$ & 12 & 19 & 15 & 9 & $\mathrm{R}$ & $\mathrm{R}$ & $\mathrm{R}$ & 11 & $\mathrm{R}$ & $\mathrm{R}$ & $\mathrm{R}$ \\
\hline H30 & & 21 & 38 & $\mathrm{R}$ & 12 & 19 & 16 & 10 & $\mathrm{R}$ & $\mathrm{R}$ & $\mathrm{R}$ & 11 & $\mathrm{R}$ & $\mathrm{R}$ & $\mathrm{R}$ \\
\hline $\mathrm{BC}$ & & 24 & 30 & $\mathrm{R}$ & $\mathrm{R}$ & $\mathrm{R}$ & 11 & $\mathrm{R}$ & $\mathrm{R}$ & $\mathrm{R}$ & $\mathrm{R}$ & $\mathrm{R}$ & $\mathrm{R}$ & $\mathrm{R}$ & $\mathrm{R}$ \\
\hline H15 & 3 & 29 & 31 & $\mathrm{R}$ & $\mathrm{R}$ & $\mathrm{R}$ & 13 & $\mathrm{R}$ & $\mathrm{R}$ & $\mathrm{R}$ & $\mathrm{R}$ & 9 & 25 & 14 & 24 \\
\hline $\mathrm{H} 30$ & & 31 & 32 & $\mathrm{R}$ & $\mathrm{R}$ & $\mathrm{R}$ & 13 & $\mathrm{R}$ & $\mathrm{R}$ & $\mathrm{R}$ & $\mathrm{R}$ & 11 & 29 & 16 & 30 \\
\hline $\mathrm{BC}$ & & 22 & $\mathrm{R}$ & $\mathrm{R}$ & 10 & 12 & 11 & $\mathrm{R}$ & $\mathrm{R}$ & $\mathrm{R}$ & $\mathrm{R}$ & $\mathrm{R}$ & $\mathrm{R}$ & $\mathrm{R}$ & $\mathrm{R}$ \\
\hline H15 & 4 & 22 & 38 & $\mathrm{R}$ & 10 & 12 & 13 & $\mathrm{R}$ & $\mathrm{R}$ & $\mathrm{R}$ & $\mathrm{R}$ & $\mathrm{R}$ & $\mathrm{R}$ & $\mathrm{R}$ & $\mathrm{R}$ \\
\hline $\mathrm{H} 30$ & & 22 & 41 & $\mathrm{R}$ & 10 & 11 & 16 & $\mathrm{R}$ & $\mathrm{R}$ & $\mathrm{R}$ & $\mathrm{R}$ & $\mathrm{R}$ & $\mathrm{R}$ & $\mathrm{R}$ & $\mathrm{R}$ \\
\hline $\mathrm{BC}$ & & 22 & 22 & $\mathrm{R}$ & $\mathrm{R}$ & $\mathrm{R}$ & 15 & $\mathrm{R}$ & $\mathrm{R}$ & $\mathrm{R}$ & $\mathrm{R}$ & $\mathrm{R}$ & $\mathrm{R}$ & $\mathrm{R}$ & $\mathrm{R}$ \\
\hline H15 & 5 & 22 & 37 & $\mathrm{R}$ & $\mathrm{R}$ & $\mathrm{R}$ & 15 & $\mathrm{R}$ & $\mathrm{R}$ & $\mathrm{R}$ & $\mathrm{R}$ & $\mathrm{R}$ & $\mathrm{R}$ & $\mathrm{R}$ & $\mathrm{R}$ \\
\hline $\mathrm{H} 30$ & & 23 & 43 & $\mathrm{R}$ & $\mathrm{R}$ & $\mathrm{R}$ & 15 & $\mathrm{R}$ & $\mathrm{R}$ & $\mathrm{R}$ & $\mathrm{R}$ & $\mathrm{R}$ & $\mathrm{R}$ & $\mathrm{R}$ & $\mathrm{R}$ \\
\hline BC & & 35 & $\mathrm{R}$ & $\mathrm{R}$ & $\mathrm{R}$ & 22 & $\mathrm{R}$ & $\mathrm{R}$ & $\mathrm{R}$ & $\mathrm{R}$ & $\mathrm{R}$ & 19 & 23 & 23 & 19 \\
\hline H15 & 6 & 38 & 22 & $\mathrm{R}$ & $\mathrm{R}$ & 22 & $\mathrm{R}$ & $\mathrm{R}$ & $\mathrm{R}$ & $\mathrm{R}$ & $\mathrm{R}$ & 23 & 26 & 25 & 20 \\
\hline $\mathrm{H} 30$ & & 42 & 25 & $\mathrm{R}$ & $\mathrm{R}$ & 23 & $\mathrm{R}$ & $\mathrm{R}$ & $\mathrm{R}$ & $\mathrm{R}$ & $\mathrm{R}$ & 23 & 31 & 31 & 20 \\
\hline $\mathrm{BC}$ & & 29 & $\mathrm{R}$ & $\mathrm{R}$ & $\mathrm{R}$ & 23 & $\mathrm{R}$ & $\mathrm{R}$ & $\mathrm{R}$ & $\mathrm{R}$ & $\mathrm{R}$ & 22 & 26 & 19 & 22 \\
\hline H15 & 7 & 33 & 21 & $\mathrm{R}$ & $\mathrm{R}$ & 23 & $\mathrm{R}$ & $\mathrm{R}$ & $\mathrm{R}$ & $\mathrm{R}$ & $\mathrm{R}$ & 28 & 27 & 19 & 25 \\
\hline $\mathrm{H} 30$ & & 36 & 28 & $\mathrm{R}$ & $\mathrm{R}$ & 26 & $\mathrm{R}$ & $\mathrm{R}$ & $\mathrm{R}$ & $\mathrm{R}$ & $\mathrm{R}$ & 30 & 30 & 20 & 26 \\
\hline $\mathrm{BC}$ & & 22 & $\mathrm{R}$ & $\mathrm{R}$ & $\mathrm{R}$ & $\mathrm{R}$ & $\mathrm{R}$ & $\mathrm{R}$ & $\mathrm{R}$ & $\mathrm{R}$ & $\mathrm{R}$ & $\mathrm{R}$ & $\mathrm{R}$ & $\mathrm{R}$ & $\mathrm{R}$ \\
\hline H15 & 8 & 26 & 20 & $\mathrm{R}$ & $\mathrm{R}$ & $\mathrm{R}$ & $\mathrm{R}$ & $\mathrm{R}$ & $\mathrm{R}$ & $\mathrm{R}$ & $\mathrm{R}$ & $\mathrm{R}$ & $\mathrm{R}$ & $\mathrm{R}$ & $\mathrm{R}$ \\
\hline H30 & & 27 & 22 & $\mathrm{R}$ & $\mathrm{R}$ & $\mathrm{R}$ & $\mathrm{R}$ & $\mathrm{R}$ & $\mathrm{R}$ & $\mathrm{R}$ & $\mathrm{R}$ & $\mathrm{R}$ & 11 & $\mathrm{R}$ & $\mathrm{R}$ \\
\hline $\mathrm{BC}$ & & $\mathrm{R}$ & 29 & $\mathrm{R}$ & $\mathrm{R}$ & 19 & $\mathrm{R}$ & $\mathrm{R}$ & $\mathrm{R}$ & $\mathrm{R}$ & 23 & 23 & 29 & 26 & 25 \\
\hline H15 & 9 & 22 & 33 & $\mathrm{R}$ & $\mathrm{R}$ & 19 & $\mathrm{R}$ & $\mathrm{R}$ & $\mathrm{R}$ & $\mathrm{R}$ & 27 & 25 & 29 & 27 & 27 \\
\hline H30 & & 27 & 38 & $\mathrm{R}$ & $\mathrm{R}$ & 19 & $\mathrm{R}$ & $\mathrm{R}$ & $\mathrm{R}$ & $\mathrm{R}$ & 28 & 28 & 32 & 30 & 29 \\
\hline $\mathrm{BC}$ & & $\mathrm{R}$ & 29 & $\mathrm{R}$ & $\mathrm{R}$ & 20 & $\mathrm{R}$ & $\mathrm{R}$ & $\mathrm{R}$ & $\mathrm{R}$ & 22 & 23 & 28 & 25 & 22 \\
\hline H15 & 10 & 23 & 34 & $\mathrm{R}$ & $\mathrm{R}$ & 22 & $\mathrm{R}$ & $\mathrm{R}$ & $\mathrm{R}$ & $\mathrm{R}$ & 27 & 27 & 29 & 28 & 25 \\
\hline H30 & & 26 & 38 & $\mathrm{R}$ & $\mathrm{R}$ & 22 & $\mathrm{R}$ & $\mathrm{R}$ & $\mathrm{R}$ & $\mathrm{R}$ & 29 & 30 & 33 & 29 & 29 \\
\hline $\mathrm{BC}$ & & 30 & $\mathrm{R}$ & $\mathrm{R}$ & 23 & 21 & $\mathrm{R}$ & $\mathrm{R}$ & $\mathrm{R}$ & $\mathrm{R}$ & 24 & 29 & 28 & 22 & 26 \\
\hline H15 & 11 & 38 & 22 & $\mathrm{R}$ & 23 & 22 & $\mathrm{R}$ & $\mathrm{R}$ & $\mathrm{R}$ & $\mathrm{R}$ & 25 & 31 & 33 & 25 & 26 \\
\hline H30 & & 41 & 28 & $\mathrm{R}$ & 23 & 21 & $\mathrm{R}$ & $\mathrm{R}$ & $\mathrm{R}$ & $\mathrm{R}$ & 25 & 33 & 36 & 30 & 33 \\
\hline
\end{tabular}

Table 6: Curing of Shigella spp., plasmid by sub culture

\begin{tabular}{|c|c|c|c|c|c|c|c|c|c|c|c|c|c|c|c|}
\hline Treatment & Isolate & CIP & $\mathrm{C}$ & $\mathrm{KF}$ & E & AZM & $\mathrm{K}$ & RA & PRL & $\mathrm{AX}$ & $\mathrm{T}$ & CAZ & CTX & FEP & CFM \\
\hline $\mathrm{BC}$ & 1 & 25 & 30 & $\mathrm{R}$ & $\mathrm{R}$ & 12 & 13 & $\mathrm{R}$ & $\mathrm{R}$ & $\mathrm{R}$ & $\mathrm{R}$ & 11 & $\mathrm{R}$ & $\mathrm{R}$ & $\mathrm{R}$ \\
\hline $\mathrm{SC}$ & & 25 & 30 & $\mathrm{R}$ & 11 & 27 & 20 & $\mathrm{R}$ & $\mathrm{R}$ & $\mathrm{R}$ & $\mathrm{R}$ & 20 & 21 & 19 & $\mathrm{R}$ \\
\hline $\mathrm{BC}$ & 2 & 22 & 32 & $\mathrm{R}$ & 12 & 20 & 12 & 9 & $\mathrm{R}$ & $\mathrm{R}$ & $\mathrm{R}$ & 10 & $\mathrm{R}$ & $\mathrm{R}$ & $\mathrm{R}$ \\
\hline $\mathrm{SC}$ & & 32 & 32 & $\mathrm{R}$ & 12 & 25 & 21 & $\mathrm{R}$ & $\mathrm{R}$ & $\mathrm{R}$ & $\mathrm{R}$ & 10 & $\mathrm{R}$ & $\mathrm{R}$ & $\mathrm{R}$ \\
\hline BC & 3 & 24 & 30 & $\mathrm{R}$ & $\mathrm{R}$ & $\mathrm{R}$ & 11 & $\mathrm{R}$ & $\mathrm{R}$ & $\mathrm{R}$ & $\mathrm{R}$ & $\mathrm{R}$ & $\mathrm{R}$ & $\mathrm{R}$ & $\mathrm{R}$ \\
\hline SC & & 30 & 30 & $\mathrm{R}$ & $\mathrm{R}$ & $\mathrm{R}$ & 11 & $\mathrm{R}$ & $\mathrm{R}$ & $\mathrm{R}$ & $\mathrm{R}$ & $\mathrm{R}$ & $\mathrm{R}$ & $\mathrm{R}$ & $\mathrm{R}$ \\
\hline $\mathrm{BC}$ & 4 & 22 & 21 & $\mathrm{R}$ & 10 & 12 & 11 & $\mathrm{R}$ & $\mathrm{R}$ & $\mathrm{R}$ & $\mathrm{R}$ & $\mathrm{R}$ & $\mathrm{R}$ & $\mathrm{R}$ & $\mathrm{R}$ \\
\hline $\mathrm{SC}$ & & 33 & 21 & $\mathrm{R}$ & 11 & 12 & 11 & $\mathrm{R}$ & $\mathrm{R}$ & $\mathrm{R}$ & $\mathrm{R}$ & $\mathrm{R}$ & $\mathrm{R}$ & $\mathrm{R}$ & $\mathrm{R}$ \\
\hline $\mathrm{BC}$ & 5 & 22 & 22 & $\mathrm{R}$ & $\mathrm{R}$ & $\mathrm{R}$ & 15 & $\mathrm{R}$ & $\mathrm{R}$ & $\mathrm{R}$ & $\mathrm{R}$ & $\mathrm{R}$ & $\mathrm{R}$ & $\mathrm{R}$ & $\mathrm{R}$ \\
\hline SC & & 31 & 22 & $\mathrm{R}$ & $\mathrm{R}$ & $\mathrm{R}$ & 15 & $\mathrm{R}$ & $\mathrm{R}$ & $\mathrm{R}$ & $\mathrm{R}$ & 20 & 21 & 19 & $\mathrm{R}$ \\
\hline $\mathrm{BC}$ & 6 & 35 & $\mathrm{R}$ & $\mathrm{R}$ & $\mathrm{R}$ & 22 & $\mathrm{R}$ & $\mathrm{R}$ & $\mathrm{R}$ & $\mathrm{R}$ & $\mathrm{R}$ & 19 & 23 & 23 & 19 \\
\hline SC & & 35 & $\mathrm{R}$ & $\mathrm{R}$ & 10 & 27 & 19 & $\mathrm{R}$ & $\mathrm{R}$ & $\mathrm{R}$ & $\mathrm{R}$ & 19 & 26 & 25 & 21 \\
\hline $\mathrm{BC}$ & 7 & 29 & $\mathrm{R}$ & $\mathrm{R}$ & $\mathrm{R}$ & 23 & $\mathrm{R}$ & $\mathrm{R}$ & $\mathrm{R}$ & $\mathrm{R}$ & $\mathrm{R}$ & 22 & 26 & 19 & 22 \\
\hline $\mathrm{SC}$ & & 29 & $\mathrm{R}$ & $\mathrm{R}$ & 11 & 24 & 20 & 10 & $\mathrm{R}$ & $\mathrm{R}$ & $\mathrm{R}$ & 23 & 26 & 19 & 22 \\
\hline $\mathrm{BC}$ & 8 & 22 & $\mathrm{R}$ & $\mathrm{R}$ & $\mathrm{R}$ & $\mathrm{R}$ & $\mathrm{R}$ & $\mathrm{R}$ & $\mathrm{R}$ & $\mathrm{R}$ & $\mathrm{R}$ & $\mathrm{R}$ & $\mathrm{R}$ & $\mathrm{R}$ & $\mathrm{R}$ \\
\hline SC & & 26 & $\mathrm{R}$ & $\mathrm{R}$ & 10 & 27 & 19 & $\mathrm{R}$ & $\mathrm{R}$ & $\mathrm{R}$ & $\mathrm{R}$ & 17 & 23 & 19 & $\mathrm{R}$ \\
\hline $\mathrm{BC}$ & 9 & $\mathrm{R}$ & 29 & $\mathrm{R}$ & $\mathrm{R}$ & 19 & $\mathrm{R}$ & $\mathrm{R}$ & $\mathrm{R}$ & $\mathrm{R}$ & 23 & 23 & 29 & 26 & 25 \\
\hline SC & & 12 & 20 & $\mathrm{R}$ & $\mathrm{R}$ & 21 & $\mathrm{R}$ & $\mathrm{R}$ & $\mathrm{R}$ & $\mathrm{R}$ & 23 & 23 & 30 & 26 & 26 \\
\hline $\mathrm{BC}$ & 10 & $\mathrm{R}$ & 29 & $\mathrm{R}$ & $\mathrm{R}$ & 20 & $\mathrm{R}$ & $\mathrm{R}$ & $\mathrm{R}$ & $\mathrm{R}$ & 22 & 23 & 28 & 25 & 22 \\
\hline $\mathrm{SC}$ & & 13 & 30 & $\mathrm{R}$ & $\mathrm{R}$ & 20 & $\mathrm{R}$ & $\mathrm{R}$ & $\mathrm{R}$ & $\mathrm{R}$ & 24 & 23 & 28 & 26 & 22 \\
\hline $\mathrm{BC}$ & 11 & 30 & $\mathrm{R}$ & $\mathrm{R}$ & 23 & 21 & $\mathrm{R}$ & $\mathrm{R}$ & $\mathrm{R}$ & $\mathrm{R}$ & 24 & 29 & 28 & 22 & 26 \\
\hline SC & & 30 & $\mathrm{R}$ & $\mathrm{R}$ & 23 & 27 & 18 & $\mathrm{R}$ & $\mathrm{R}$ & $\mathrm{R}$ & 24 & 29 & 28 & 22 & 26 \\
\hline
\end{tabular}


Am. J. Microbiology 1 (1): 1-8, 2010

Table 7: Curing of Shigella spp., plasmid by ethidium bromide

\begin{tabular}{|c|c|c|c|c|c|c|c|c|c|c|c|c|c|c|c|}
\hline Treatment & Isolate & CIP & $\mathrm{C}$ & $\mathrm{KF}$ & E & AZM & $\mathrm{K}$ & RA & PRL & $\mathrm{AX}$ & $\mathrm{T}$ & CAZ & CTX & FEP & CFM \\
\hline $\mathrm{BC}$ & & 25 & 30 & $\mathrm{R}$ & $\mathrm{R}$ & 12 & 13 & $\mathrm{R}$ & $\mathrm{R}$ & $\mathrm{R}$ & $\mathrm{R}$ & 11 & $\mathrm{R}$ & $\mathrm{R}$ & $\mathrm{R}$ \\
\hline E31.25 & 1 & 29 & 32 & $\mathrm{R}$ & $\mathrm{R}$ & 24 & 20 & $\mathrm{R}$ & $\mathrm{R}$ & $\mathrm{R}$ & $\mathrm{R}$ & 11 & 26 & 15 & 16 \\
\hline E62.5 & & 29 & 37 & $\mathrm{R}$ & $\mathrm{R}$ & 24 & 21 & $\mathrm{R}$ & $\mathrm{R}$ & $\mathrm{R}$ & $\mathrm{R}$ & 15 & 27 & 15 & 16 \\
\hline BC & & 22 & 32 & $\mathrm{R}$ & 12 & 20 & 12 & 9 & $\mathrm{R}$ & $\mathrm{R}$ & $\mathrm{R}$ & 10 & $\mathrm{R}$ & $\mathrm{R}$ & $\mathrm{R}$ \\
\hline E31.25 & 2 & 22 & 33 & $\mathrm{R}$ & 13 & 22 & 12 & 10 & $\mathrm{R}$ & $\mathrm{R}$ & $\mathrm{R}$ & 10 & 9 & 8 & $\mathrm{R}$ \\
\hline E62.5 & & I & I & / & I & I & I & I & I & I & I & I & I & I & I \\
\hline BC & & 24 & 30 & $\mathrm{R}$ & $\mathrm{R}$ & $\mathrm{R}$ & 11 & $\mathrm{R}$ & $\mathrm{R}$ & $\mathrm{R}$ & $\mathrm{R}$ & $\mathrm{R}$ & $\mathrm{R}$ & $\mathrm{R}$ & $\mathrm{R}$ \\
\hline E31.25 & 3 & 43 & 40 & $\mathrm{R}$ & $\mathrm{R}$ & 31 & 25 & 5 & 5 & 5 & 5 & 30 & 42 & 22 & 25 \\
\hline E62.5 & & I & I & I & I & I & I & I & I & I & I & I & I & I & I \\
\hline BC & & 22 & $\mathrm{R}$ & $\mathrm{R}$ & 10 & 12 & 11 & $\mathrm{R}$ & $\mathrm{R}$ & $\mathrm{R}$ & $\mathrm{R}$ & $\mathrm{R}$ & $\mathrm{R}$ & $\mathrm{R}$ & $\mathrm{R}$ \\
\hline E31.25 & 4 & 30 & $\mathrm{R}$ & $\mathrm{R}$ & 10 & 24 & 19 & $\mathrm{R}$ & $\mathrm{R}$ & $\mathrm{R}$ & $\mathrm{R}$ & 17 & 25 & 14 & 16 \\
\hline E62.5 & & I & I & I & I & I & I & I & I & I & I & I & I & 1 & 1 \\
\hline BC & & 22 & 22 & $\mathrm{R}$ & $\mathrm{R}$ & $\mathrm{R}$ & 15 & $\mathrm{R}$ & $\mathrm{R}$ & $\mathrm{R}$ & $\mathrm{R}$ & $\mathrm{R}$ & $\mathrm{R}$ & $\mathrm{R}$ & $\mathrm{R}$ \\
\hline E31.25 & 5 & 30 & 24 & $\mathrm{R}$ & $\mathrm{R}$ & $\mathrm{R}$ & 15 & $\mathrm{R}$ & $\mathrm{R}$ & $\mathrm{R}$ & $\mathrm{R}$ & $\mathrm{R}$ & $\mathrm{R}$ & $\mathrm{R}$ & $\mathrm{R}$ \\
\hline E62.5 & & I & 1 & I & I & 1 & I & I & I & I & I & I & I & 1 & 1 \\
\hline BC & & 35 & $\mathrm{R}$ & $\mathrm{R}$ & $\mathrm{R}$ & 22 & $\mathrm{R}$ & $\mathrm{R}$ & $\mathrm{R}$ & $\mathrm{R}$ & $\mathrm{R}$ & 19 & 23 & 23 & 19 \\
\hline E31.25 & 6 & 44 & $\mathrm{R}$ & $\mathrm{R}$ & $\mathrm{R}$ & 23 & $\mathrm{R}$ & $\mathrm{R}$ & $\mathrm{R}$ & $\mathrm{R}$ & $\mathrm{R}$ & 20 & 23 & 24 & 22 \\
\hline E62.5 & & I & I & I & I & I & I & / & I & I & I & 1 & I & 1 & 1 \\
\hline BC & & 29 & $\mathrm{R}$ & $\mathrm{R}$ & $\mathrm{R}$ & 23 & $\mathrm{R}$ & $\mathrm{R}$ & $\mathrm{R}$ & $\mathrm{R}$ & $\mathrm{R}$ & 22 & 26 & 19 & 22 \\
\hline E31.25 & 7 & 30 & $\mathrm{R}$ & $\mathrm{R}$ & $\mathrm{R}$ & 22 & 19 & $\mathrm{R}$ & $\mathrm{R}$ & $\mathrm{R}$ & $\mathrm{R}$ & 22 & 26 & 20 & 21 \\
\hline E62.5 & & 30 & $\mathrm{R}$ & $\mathrm{R}$ & $\mathrm{R}$ & 22 & 21 & $\mathrm{R}$ & $\mathrm{R}$ & $\mathrm{R}$ & $\mathrm{R}$ & 23 & 27 & 21 & 22 \\
\hline BC & & 22 & $\mathrm{R}$ & $\mathrm{R}$ & $\mathrm{R}$ & $\mathrm{R}$ & $\mathrm{R}$ & $\mathrm{R}$ & $\mathrm{R}$ & $\mathrm{R}$ & $\mathrm{R}$ & $\mathrm{R}$ & $\mathrm{R}$ & $\mathrm{R}$ & $\mathrm{R}$ \\
\hline E31.25 & 8 & 28 & $\mathrm{R}$ & $\mathrm{R}$ & $\mathrm{R}$ & 24 & 18 & $\mathrm{R}$ & $\mathrm{R}$ & $\mathrm{R}$ & $\mathrm{R}$ & 16 & 25 & 15 & 15 \\
\hline E62.5 & & I & 1 & / & / & / & 1 & I & / & I & I & I & I & I & I \\
\hline $\mathrm{BC}$ & & $\mathrm{R}$ & 29 & $\mathrm{R}$ & $\mathrm{R}$ & 19 & $\mathrm{R}$ & $\mathrm{R}$ & $\mathrm{R}$ & $\mathrm{R}$ & 23 & 23 & 29 & 26 & 25 \\
\hline E31.25 & 9 & 19 & 30 & $\mathrm{R}$ & $\mathrm{R}$ & 19 & $\mathrm{R}$ & $\mathrm{R}$ & $\mathrm{R}$ & $\mathrm{R}$ & 24 & 23 & 29 & 27 & 25 \\
\hline E62.5 & & / & I & / & I & / & I & I & / & I & / & I & / & / & I \\
\hline BC & & $\mathrm{R}$ & 29 & $\mathrm{R}$ & $\mathrm{R}$ & 20 & $\mathrm{R}$ & $\mathrm{R}$ & $\mathrm{R}$ & $\mathrm{R}$ & 22 & 23 & 28 & 25 & 22 \\
\hline E31.25 & 10 & 17 & 30 & $\mathrm{R}$ & $\mathrm{R}$ & 20 & $\mathrm{R}$ & $\mathrm{R}$ & $\mathrm{R}$ & $\mathrm{R}$ & 25 & 26 & 28 & 27 & 26 \\
\hline E62.5 & & I & 1 & I & I & I & / & / & I & / & I & I & I & I & 1 \\
\hline $\mathrm{BC}$ & & 30 & $\mathrm{R}$ & $\mathrm{R}$ & 23 & 21 & $\mathrm{R}$ & $\mathrm{R}$ & $\mathrm{R}$ & $\mathrm{R}$ & 24 & 29 & 28 & 22 & 26 \\
\hline E31.25 & 11 & 33 & $\mathrm{R}$ & $\mathrm{R}$ & 22 & 21 & $\mathrm{R}$ & $\mathrm{R}$ & $\mathrm{R}$ & $\mathrm{R}$ & 24 & 28 & 28 & 23 & 26 \\
\hline E62.5 & & 34 & $\mathrm{R}$ & $\mathrm{R}$ & 23 & 21 & $\mathrm{R}$ & $\mathrm{R}$ & $\mathrm{R}$ & $\mathrm{R}$ & 24 & 28 & 28 & 23 & 26 \\
\hline
\end{tabular}

\section{CONCLUSION}

Approximately $89.5 \%$ of the diarrhea cases had no bacterial pathogen, suggested of probability of viral infection. Similar to other studies (Patel et al., 2008) which indicated that $84 \%$ of diarrheal patients caused by other microorganism than other bacteria.

\section{REFERENCES}

Ahmed, F., J.D. Clemens, M.R. Rao, M. Ansaruzzaman and E. Haque, 1997. Epidemiology of shigellosis among children exposed to cases of Shigella dysentery: A multivariate assessment. Am. J. Trop. Med. $\quad$ Hyg., 56 : 258-64. http://www.ajtmh.org/cgi/content/abstract/56/3/258

Alhaj, N.A., M.N. Shamsudin, H.F. Zamri and R. Abdullah, 2008. Extraction of essential oil from Nigella sativa using supercritical carbon dioxide: Study of antibacterial activity. Am. J. Pharm. Toxicol., 3: 225-228. DOI: 10.3844/.2008.225.228

Altalhi, A. D. 2007. Plasmid-mediated detoxification of mycotoxin zearalenone in Pseudomonas sp. ZEA1. Am. J. Biotechnol. Biochem., 3: 150-158. DOI: $10.3844 / .2007 .150 .158$
Ansari, F.A. and H. Khatoon, 1997. Curing of R plasmids present in gram negative bacteria isolated from poultry in Karachi by ethidium bromide. Pak. J. Pharm. Sci., 10: 13-16. http://www.pjps.pk/CDPJPS-10-2-97/Paper-2.pdf

Banajeh, S.M., N.H. Ba-Oum and R.M. Al-Sanabani, 2001. Bacterial aetiology and antimicrobial resistance of childhood diarrhea in Yemen. J. Trop. Pediatr., 47: 301-303.

Chu, Y.W., E.T. Houang, D.J. Lyon, J.M. Ling, T.K. $\mathrm{Ng}$ and A.F. Cheng, 1998. Antimicrobial resistance in shigella flexneri and shigella sonnei in Hong Kong, 1986-1995. Antimicrob. Agents Chemother., 42: 440-443.

Chuang, Y.Y., Y.C. Huang and S.Y. Lin, 2006. Outbreak of Shigella sonnei gastroenteritis in Northeastern Taiwan. Pediatr. Infect. Dis. J., 25: 92-94. PMID: 16395118

Essers, B., A.P. Burnens, F.M. Lanfranchini, S.G.E. Somaruga and R.O. von Vigier et al., 2000. Acute community-acquired diarrhea requiring hospital admission in Swiss children. Clin. Infect. Dis., 31: 192-196. http://www.jstor.org/stable/4482290 
Farshad, S., R. Sheikhi, A. Japoni, E. Basiri and A. Alborzi, 2006. Characterization of shigella strains in Iran by plasmid profile analysis and PCR amplification of ipa genes. J. Clin. Microbiol., 44: 2879-2883. DOI: 10.1128/JCM.00310-06

Gascon, J., M. Vargas, D. Schellenberg, H. Urassa and C. Casals et al., 2000. Diarrhea in children under 5 years of age from Ifakara, Tanzania: A casecontrol study. J. Clin. Microbiol., 38: 4459-4462. http://jcm.asm.org/cgi/content/abstract/38/12/4459

Haider, K., M.I. Huq, A.R. Samadi and K. Ahmad, 1985. Plasmid characterization of Shigella spp. isolated from children with shigellosis and asymptomatic excretors. J. Antimicrob. Chemother., 16: 691-698. PMID: 3912364

Hawari, A.D., 2008. Corynebacterium pseudotuberculosis infection (Caseous lymphadenitis) in Camels (Camelus dromedarius) in Jordan. Am. J. Anim. Vet. Sci., 3: 68-72. DOI: 10.3844/.2008.68.72

Kado, C.I. and S.T. Liu, 1981. Rapid procedure for detection and isolation of large and small plasmids. J. Bacteriol., 145: 1365-1373. PMID: 7009583

Kamiunten, H., 1990. Loss of a plasmid in pseudomonas syringae pv. eriobotryae is correlated with change of symptoms. Ann. Phytopath. Soc. Jap., 56: 645-650. http//:hdl.handle.net/10458/2517

Katouli, M., A. Jaafari, A.A. Farhoudi-Moghaddam and G.R. Ketabi, 1990. Aetiological studies of diarrhoeal diseases in infants and young children in Iran. J. Trop Med. Hyg., 93: 22-27. PMID: 2406458

Kotloff, K.L., J.P. Winickoff, B. Ivanoff, J.D. Clemens and D.L. Swerdlow et al., 1999. Global burden of Shigella infections: Implications for vaccine development and implementation of control strategies. Bull. World Health Org., 77: 651-666. PMID: 10516787

Kuo, C.Y., L.H. Su, J. Perera, C. Carlos and B.H. Tan et al., 2008. Antimicrobial susceptibility of Shigella isolates in eight Asian countries, 20012004. J. Microbiol. Immunol. Infect., 41: 107-111. PMID: 18473096

Litwin, C.M., A.L. Storm, S. Chipowsky and K.J. Ryan, 1991. Molecular epidemiology of shigella infections: Plasmid profiles, serotype correlation and restriction endonuclease analysis. J. Clin. Microbiol., 29: 104-108. PMCID: PMC269712

Mandomando, I., D. Jaintilal, M.J. Pons, X. Valles and M. Espasa et al., 2009. Antimicrobial susceptibility and mechanisms of resistance in Shigella and Salmonella isolates from children under five years of age with diarrhea in rural mozambique. Antimicrob. Agents Chemother., 53: 2450-2454. DOI: 10.1128/AAC.01282-08
Maniatis, T., 1982. Molecular Cloning: A Laboratory Manual. 3rd Edn., Cold Spring Harbor Laboratory, New York, ISBN: 10: 0879691360, pp: 545.

Mesas, J.M., M.C. Rodriguez and T.M. Alegrec, 2004. Plasmid curing of Oenococcus oeni. Plasmid, 51: 37-40. DOI: 10.1016/S0147-619X(03)00074-X

MoezArdalan, K., M.R. Zali1, M.M.S. Dallal, M.R. Hemami and S. Salmanzadeh-Ahrabi1, 2003. Prevalence and pattern of antimicrobial resistance of shigella species among patients with acute Diarrhoea in Karaj, Tehran, Iran. J. Health Popul. Nutr., 21: 96-102. PMID: 13677436

National Committee for Clinical Laboratory Standards, 2002. The performance standard for antimicrobial susceptibility testing methods. National Committee for Clinical Laboratory Standards.

Ozuah, P.O., 1998. Shigella update. Pediatr. Rev., 19: 100-100. DOI: 10.1542/pir.19-3-100

Parashar, U.D., R.C. Holman, J.S. Bresee, M.J. Clarke and P.H. Rhodes et al., 1998. Epidemiology of diarrheal disease among children enrolled in four West Coast health maintenance organizations. Pediatr. Infect. Dis. J., 17: 605-611. PMID: 9686726

Patel, P.K., J. Mercy, J. Shenoy and B. Ashwini, 2008. Factors associated with acute diarrhoea in children in Dhahira, Oman: A hospital-based study. East. Mediterr. Health J., 14: 571-578.

Raja, C.E. and G.S. Selvam, 2009. Plasmid profile and curing analysis of Pseudomonas aeruginosa as metal resistant. Int. J. Environ. Sci. Technol., 6: 259-266. http://www.bioline.org.br/pdf?st09029

Raja, S.B., M.R. Murali, G.K. Malathi, K. Anbarasu and S.N. Devaraj, 2009. Effect of aqueous extract of Aegle marmelos fruit on adherence and $\beta$-lactam resistance of Enteropathogenic Escherichia coli by down regulating outer membrane protein C. Am. J. Infect. Dis., 5: 154-162. DOI: 10.3844/.2009.154.162

Rawashdeh, M.O., A.M. Ababneh and A.A. Shurman, 1994. Shigellosis in Jordanian children: A clinicoepidemiologic prospective study and susceptibility to antibiotics. J. Trop. Pediatr., 40: 355-359. DOI: 10.1093/tropej/40.6.355

Sansonetti, P.J., D.J. Kopecko and S.B. Formal, 1981. Shigella sonnei plasmids: Evidence that a large plasmid is necessary for virulence. Infect. Immun., 34: 75-83. PMCID: PMC350823

Shafik, M.H., H.Y. Al-Quattan and M.T. Mohamed, 2007. Fulminating Shigella encephalopathy (Ekiri syndrome): A case report. Kuwait Med. J., 39: 369-372. 
Smith, S.I., O.O. Aboaba, P. Odeigha, K. Shodyo and J.A. Adeyeye et al., 2003. Plasmids profiles Escherichia coli 0157:H7 from apparently healthy animals. Afr. J. Biotechnol., 35: 42-47.

Tacket, C.O., N. Shahid, M.I. Huq, A.R. Alim and M.L. Cohen, 1984. Usefulness of plasmid profiles for differentiation of Shigella isolates in Bangladesh. J. Clin. Microbiol., 20: 300-301. PMCID: PMC271311

Wasfy, M.O., B.A. Oyofo, J.C. David, T.F. Ismail and A.M. El-Gendy et al., 2000. Isolation and antibiotic susceptibility Salmonella, Shigella and Campylobacter from acute enteric infections in Egypt. J. Health Popul. Nutr., 18: 33-38. PMID: 11014768
Zurkowski, W. and Z. Lorkiewicz, 1978. Effective method for the isolation of non-nodulatiog mutants of Rhizobium trifolii. Genet. Res., 32: 311-314. DOI: $10.1017 /$ S0016672300018814 